\title{
Interaction between spermatozoa and the mare's reproductive tract is mediated by biochemical, physical, and inflammatory mechanisms
}

\author{
Mats H. T. Troedsson \\ Department of Large Animal Clinical Sciences, College of Veterinary Medicine, University of Florida, Gainesville, FL 32610
}

\begin{abstract}
Summary
Sperm transport and elimination from the mare's reproductive tract are important components of the events that lead to fertilization and successful development of an embryo. Following deposition of semen into the uterine body, viable spermatozoa are transported to the oviduct by a combination of sperm motility, uterine contractility, and epithelial cilia activity. This process is facilitated by the release of oxytocin from the pituitary, as well as prostaglandins and estrogen in seminal plasma. The myoelectrical activity in the uterus shows a two-wave pattern following Al. The first immediate phase of contractions is believed to be involved in both sperm transport to the oviduct, and elimination of excess spermatozoa through the cervix. The second phase of contractions coincides with an inflammatory response to spermatozoa. The inflammation is an important physiological component of sperm elimination from the mare's reproductive tract. It is regulated by seminal components. Spermatozoa activate complement in uterine secretion, resulting in chemotaxis of PMNs into the uterine lumen. The PMNs bind to spermatozoa that consequently are removed from the uterus by phagocytosis. Inflammatory mediators, such as PGF2 $\alpha$, cause contraction of the myometrium, and residual spermatozoa, accumulated fluid, and harmful inflammatory products are removed by this second wave of uterine contractions. Once these products are removed from the uterine lumen, the inflammation subsides and the uterine environment returns to its normal state. Specific seminal plasma proteins modulate breeding-induced endometritis, and appear to selectively protect viable spermatozoa from binding to PMNs.
\end{abstract}

Keywords: mare, post-breeding-endometritis, uterine clearance, spermatozoa, inseminate components

Der Einfluss von biochemischen, physikalischen und entzündlichen Mechanismen bei den Interaktionen zwischen Spermatozoen und dem Genitaltrakt der Stute

Der Transport der Spermien und ihre Elimination aus dem Stutengenitale stellen wichtige Komponenten innerhalb der Vorgänge dar, die zur Konzeption und zur erfolgreichen Entwicklung des Embryos führen. Nach dem Verbringen des Samens in die Gebärmutter werden lebensfähige Spermatozoen in die Eileiter transportiert. Dies geschieht durch eine Kombination von Spermienmotilität, uterinen Kontraktionen und epithelialer Zilienaktivität. Dieser Prozess wird unterstützt durch die Oxyłocinfreisetzung aus der Hypophyse sowie durch Prostaglandine und Östrogen im Seminalplasma. Die myoelektrische Aktivität des Uterus weist nach der instrumentellen Samenübertragung eine zweifache Wellenbewegung auf. Die erste, sofort einsetzende Kontraktionsphase ist vermutlich sowohl beim Spermientransport in den Eileiter als auch bei der Elimination überschüssiger Spermatozoen durch die Zervix involviert. Die zweite Phase der Kontraktionen trifft mit der Entzündungsreaktion auf die Spermatozoen zusammen. Die Entzündung ist ein wichtiger physiologischer Bestandteil bei der Spermienelimination aus dem Stutengeniale. Sie wird durch die Seminalkomponenten reguliert. Spermatozoen aktivieren das Komplementsystem im uterinen Sekret, resultierend in einer Chemotaxis für neutrophile Granulozyten (PMNs) in das Uteruslumen. Die PMNs gehen mit den Spermatozoen eine Verbindung ein, durch Phagozytose werden die Spermatozoen dann aus dem Uterus entfernt. Entzündungsmediatoren, wie PGF2 $\alpha$, verursachen myometriale Kontraktionen und die restlichen Spermatozoen, Flüssigkeitsansammlungen und schädliche Entzündungsprodukte werden durch diese zweite Kontraktionswelle des Uterus eliminiert. Sobald diese Produkte aus dem Uteruslumen entfernt sind, klingt die Entzündung ab und der Normalzustand des Uterusmilieus ist wieder hergestellt. Bestimmte Proteine des Seminalplasmas modulieren die durch die Bedeckung/Besamung induzierte Endometritis und scheinen lebensfähige Spermatozoen vor einer Bindung mit den PMNs selektiv zu schützen.

Schlüsselwörter: Stute, post-breeding-endometritis, uterine clearance, Spermien, Inseminatkomponenten

\section{Introduction}

Although in vitro fertilization techniques can eliminate many biological events that proceed fertilization, important interactions between spermatozoa and other seminal components on one hand, and the uterus and oviduct on the other hand are required in mares that are bred naturally or by artificial insemination (Al). A population of viable and fertile spermatozoa needs to be transported to the site of fertilization in the oviduct, sperm viability need to be maintained until after ovulation, spermatozoa need to undergo capacitation in order to penetrate the ovum, and excess and non-viable spermatozoa need to be eliminated from the uterus. In addition to motility and morphology of the spermatozoa, factors such as biochemical characteristics of sperm cells and seminal plasma, uterine contractility, and the micro-environment of the female reproductive tract might be essential components for successful fertilization to take place. This is supported by studies on both horses and other species, suggesting that the integrity of the macromolecules of the sperm membrane is an important component of sperm longevity in sows (Pavelko and Crabo 1976), that uterine contractility in response to semen may be 
associated with sperm transport in the mare (Katila et al. 2000), that sperm transport is affected by prostaglandin in ram semen (Gustavsson et al. 1977), and that membrane biochemistry is important for sperm capacitation, acrosome reaction and the final steps of fertilization (Hunter and Nornes 1969). All these factors may affect transport and survival of viable spermatozoa, and elimination of non-viable and excess spermatozoa from the mare's reproductive tract. The objective of this review is to summarize the current understanding of the interaction between spermatozoa and the mare's reproductive tract during sperm transport and elimination from the uterus.

\section{Sperm transport}

\section{Uterine transport}

Semen is deposited into the uterine lumen of the mare during both natural breeding and artificial insemination. Spermatozoa are quickly transported to the oviduct by a combination of sperm motility, uterine motility, and epithelial cilia activity. Rapid transport of a small number of spermatozoa through the female tract into the peritoneal cavity following mating has been described in several species, but not in the mare (Phillips and Andrews 1937, VanDemark and Moeller 1951, Overstreet and Cooper 1978). However, spermatozoa have been identified in the oviduct already within 1 hour after insemination, and sperm transport is thought to be completed within 4 hours after breeding (Bader 1982; Brinsko et al. 1990, 1991, Scott et al. 1994, Scott 2000). Although spermatozoa actively participate in the transport through the female reproductive tract, contractions of the myometrium and myosalpinx may be more important in regulating the transport of spermatozoa to the site of fertilization (Katila et al. 2000). Breeding stimulates contractions in the uterine and oviductal smooth muscle layers (Drobnis and Overstreet 1992, Fuchs 1972, Troedsson et al. 1998). Using electromyography (EMG) to monitor myometrial activity following $\mathrm{Al}$, an immediate increase in myoelectrical activity that lasted for 0.5 hours was observed (Figure 1, Troedsson et al. 1998). The mechanism of this rapid myometrial response to insemination is not fully understood, but ecbolic hormones are believed to play an important role. Equine seminal plasma contains both prostaglandins and estrogen (Claus et al. 1992). In addition, pituitary release of oxytocin in response to $\mathrm{Al}$ and social interactions with a stallion has been associated with increased myoelectrical activity (Figure 2, Madill et al. 2000). This may be an important mechanism by which semen is transported from the site of deposition in the uterine body to the uterine horns.

\section{Transport across the utero-tubal junction}

The utero-tubal junction has been suggested to serve as a major sperm barrier, and the oviductal portion of the uterotubal junction may also serve as a reservoir for sperm in the mare (Scott 2000). Less than 1\% of inseminated spermatozoa are successfully transported to the oviducts after insemination (Scott et al. 1995, Bader and Krause 1980). Preliminary data suggests that prostaglandin $\mathrm{E}\left(\mathrm{PGE}_{2 \alpha}\right)$ may be involved in sperm transport from the uterus to the oviduct (Troedsson et al. 2005). We have previously observed that $\mathrm{PGE}_{2 \alpha}$ causes

Die

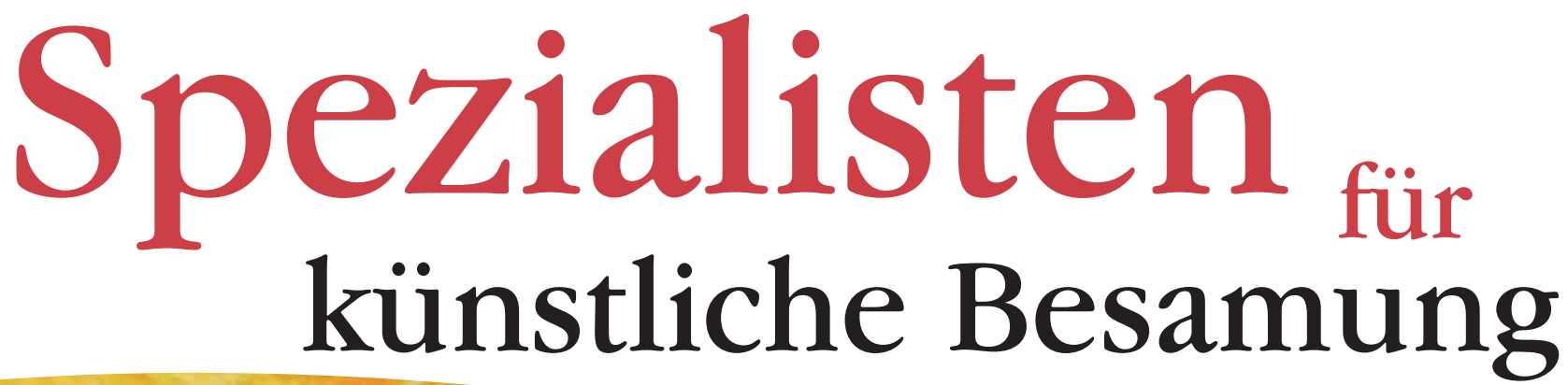

Planung und Einrichtung von Labors

Phantome

Geräte und Maschinen für das Tiefgefrieren Zubehör und Verbrauchsmaterial technischer Service und Betreuung

MINITÜB Abfüll- und Labortechnik GmbH \& Co. KG Hauptstraße $41 \cdot 84184$ Tiefenbach

Tel.: +49(0)8709-92 29 0. Fax: +49(0)8709922939

E-Mail: minitube@minitube.de.www.minitube.de 
smooth muscle contractions in the equine oviduct (Troedsson et al. 1995b). Based on studies in other species, PGE appears to exert a selective effect on the longitudinal muscle layer of the oviduct (Blair and Beck 1977, Rodriguez-Martinez and Einarsson 1985). This results in an increased diameter of the lumen, which facilitates transport of gametes through the oviduct. A similar regulatory mechanism of the junction between the uterus and the oviduct would perhaps facilitate transport of spermatozoa into the oviduct. Our data suggest that PGE $2 \alpha$ may facilitate transport of spermatozoa across the utero-tubal junction, but the number of observations was small and the results need to be confirmed using a larger sample size (Troedsson et al. 2005). Studies suggest that fertile spermatozoa are selectively transported over the utero-tubal junction. Scott et al (1995) found a selected fraction of motile and morphologically normal spermatozoa in the oviducts following insemination, but the mechanism of this selective transport of normal spermatozoa is not understood.

\section{Sperm elimination}

Increased myometrial contraction associated with breeding is believed to be responsible for rapid sperm elimination from the uterus through the cervix. However, not all excess sper-

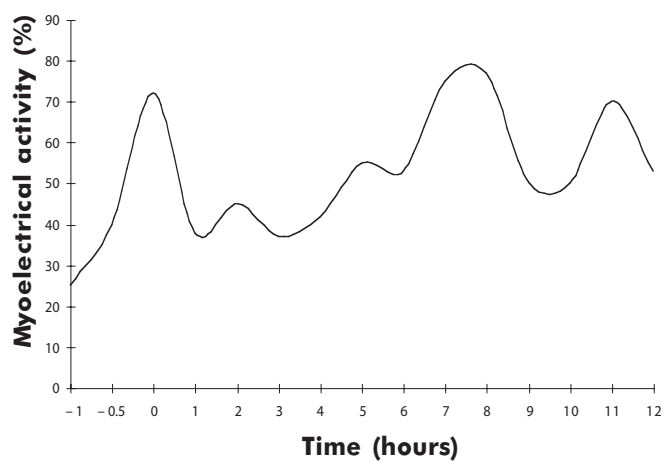

Fig 1 Total myometrial EMG activity (\% of time activity was recorded) in response to $\mathrm{Al}$ (time 0 ) in a mare. Al resulted in an immediate increase of myoelectrical activity that lasted for 0.5 hours. Following normalization to baseline activity, myoelectrical activity increased in a second phase that started 4 hours after Al. (Adapted from Troedsson et al. 1998 with permission).

Myometriale Gesamtaktivität (Elekromyographie) (Aktivität pro Zeiteinheit in \%) in bezogen auf den Zeitpunkt der Al (Zeitpunkt 0) bei der Stute. Die Al führt zu einem sofortigen Anstieg der myoelektrischen Aktivität, der für 30 Minuten anhält. Nach einer Normalisierung bis zur Basisaktivität, steigt die myoelektrische Aktivität in einer zweiten Phase 4 Stunden nach der Al wieder an. (Entnommen aus Troedsson et al. 1998. mit Erlaubnis).

matozoa are removed through this mechanism, and other uterine clearance mechanisms are necessary. These mechanisms involve a combination of innate immune reactions and mechanical clearance through a second wave of uterine contractions, which has been observed 4-12 hours after Al (Figure 1, Troedsson et al. 1998).

\section{Breeding-induced endometritis}

An influx of polymorphonuclear neutrophils (PMNs) has consistently been found in the equine uterus within a few hours of insemination (Kotilainen et al. 1994, Scott et al. 1995,
Troedsson et al. 1995a). The inflammatory response appears to be a normal process by which sperm are eliminated from the mare reproductive tract (Troedsson et al. 1998, 1999). In vitro studies suggest that spermatozoa induce PMN-chemotaxis via complement activation (Figure 3; Troedsson et al. 1995a, Rozeboom et al. 2001). Complement activity as well as isolation of complement cleavage products has been demonstrated in the equine reproductive tract (Asbury et al. 1982, Watson et al. 1987, Troedsson et al. 1993), and this is likely involved in the mechanism by which breeding-induced endometritis is induced. Activated PMNs bind to spermatozoa and although the mechanism of this binding is not yet fully understood, recent data suggest that it is mediated by extracellular neutrophil traps (NET), but also involves more traditional ligand receptor binding (Alghamdi and Foster 2005, Brinkman et al. 2004). Following binding, spermatozoa are phagocytosed by PMNs. During activation of PMNs, prostaglandin F2a (PGF2a) is released from cell membranes by metabolism of arachidonic acid via the cycloxygenase pathway. In addition to being an inflammatory mediator, PGF2a causes contraction of smooth muscle, including the myometrium (Troedsson et al. 1995b). Uterine contractions are believed to physically remove residual spermatozoa, accumulated fluid, and harmful inflammatory products that have been released during PMN-pha-

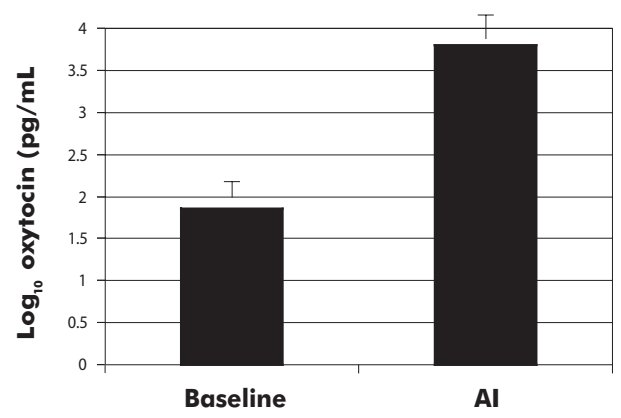

Fig 2 Peak pituitary effluent oxytocin concentrations in five mares before (baseline) and after Al. Insemination resulted in a significant increase of oxytocin release from the pituitary $(\mathrm{P}<0.05)$. (Adapted from Madill et al. 2000 with permission). Spitzenwerte der hypophysären Oxytocinausschüttung bei fünf Stuten vor (baseline) und nach der Al. Die Besamung führt zu einem signifikanten Anstieg der Oxytocinausschüttung aus der Hypophyse $(p<0,05)$. (Entnommen aus Madill et al. 2000, mit Erlaubnis).

gocytosis (Figure 4, Troedsson 1999). Once these products are removed from the uterine lumen, inflammation subsides, and the uterine environment returns to its normal state. In mares with functional uterine defense mechanisms, the majority of inflammatory products are cleared from the uterus within 24 to 36 hours of Al (Katila 1995). The transient nature of breeding-induced endometritis is thought to be essential for normal fertility, since residual inflammation in the uterus at the time when the embryo descends from the oviduct to the uterine lumen would be detrimental to embryo survival.

\section{The role of seminal plasma}

In contrast to spermatozoa, seminal plasma has a suppressive effect on complement activation, PMN-chemotaxis, and 
phagocytosis (Dahms and Troedsson 2002, Troedsson et al. $1999,2000)$. It has therefore, been suggested that seminal plasma may act as an inflammatory modulator in the uterus and at least in part, be responsible for the transient nature of a breeding-induced inflammation. The duration of breedinginduced uterine inflammations was shown to be shorter when seminal plasma was included in an insemination dose, compared to its removal and replacement by a commercial semen extender (Troedsson et al. 2002). Seminal plasma also functions in breeding-induced endometritis to protect spermatozoa from being phagocytosed and destroyed in an inflammatory environment. The clinical importance of this is demonstrated by the results of an in vivo study, in which removal of all seminal plasma was shown to be detrimental to fertility when mares were inseminated in the presence of an active breeding-induced endometritis (Alghamdi et al. 2004). Interestingly, the fertility was restored to normal levels if seminal plasma was added back to the insemination dose. These results are supported by a previous report by Rozeboom et al. (2000), in which the investigators found that both pregnancy rates and litter sizes were improved when seminal plasma was added to the insemination dose in sows inseminated in the presence of a breeding induced uterine inflammation. The results are somewhat contradictory to a report by Metcalf (2000), which suggested that two Al with

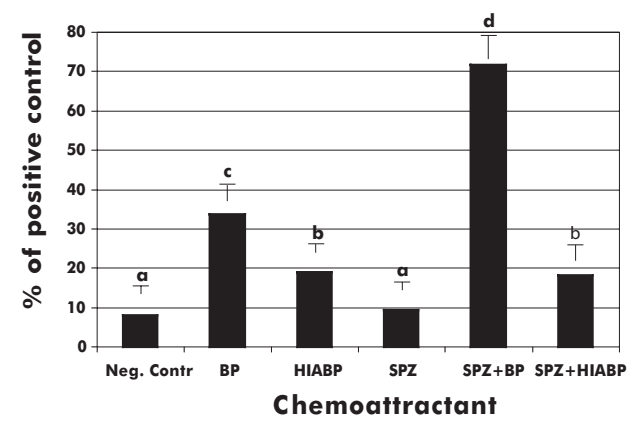

Fig 3 PMN-chemotaxis in response to different chemoattractants (Neg. Contr. = cell medium, BP = Blood plasma, HIABP = Heat inactivated blood plasma at $56 \mathrm{C}$ for 35 minutes, SPZ = Spermatozoa). Chemotaxis is expressed as percentage of a positive control (endotoxin activated blood plasma). Different letters $a, b, c, d$ indicate a significant difference between treatments $(p<0.05)$.

Einwanderung der PMNs als Antwort auf verschiedene chemotaktische Faktoren (Neg.Contr. = Zellmedium, BP = Blutplasma, HIABP = hitzeinaktiviertes Blutplasma bei $56^{\circ} \mathrm{C}$ für $35 \mathrm{~min}, \mathrm{SPZ}$ = Spermatozoen). Die Chemotaxis wird dargestellt Prozent bezogen auf eine Positivkontrolle (endotoxinaktiviertes Blutplasma). Die Buchstaben $a, b, c, d$ markieren signifikante Unterschiede zwischen den Behandlungen.

frozen/thawed semen 6-10 hours apart have equal fertility. However, while all seminal plasma was removed in the studies by Alghamdi and Rozeboom, some seminal plasma was included when semen was prepared for cryopreservation in Metcalf's study.

Selective elimination of non-viable spermatozoa from the uterus.

Because PMNs are present in the uterus before sperm transport is completed, fertile spermatozoa needs to reach the ovi- duct in the presence of a uterine inflammation. In addition, spermatozoa are deposited into an inflammatory environment when mares are bred twice within 12 to 24 hours. Experiments in rabbits suggested that a sub-population of viable spermatozoa was protected from phagocytosis in the uterus, but the mechanism was not determined (Taylor 1982). Recent data on the horse suggest that seminal plasma protects viable, but not dead spermatozoa from PMN-binding and phagocytosis (Troedsson et al. 2005). This effect appeared to be confined to a specific low molecular weight protein fraction within seminal plasma. A selective protection of viable spermatozoa from PMN-binding and phagocytosis increases their survival in a hostile uterine environment and ensure that a sufficient number of spermatozoa reach the oviduct for fertilization, while an effective sperm elimination of non-viable spermatozoa can be maintained.

\section{Conclusion}

Several biochemical, physical, and immunological reactions characterize the interaction between equine spermatozoa and the mare's reproductive tract following deposition of semen into the uterus. Although not fully understood, current data suggest that these reactions are important for the events lea-

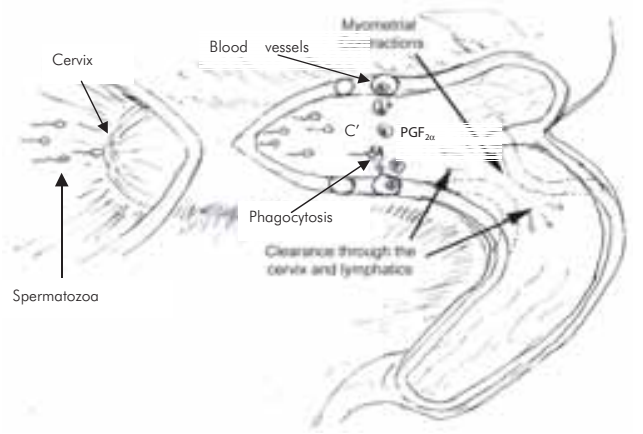

Fig 4 Proposed model of breeding-induced endometritis in mares. Spermatozoa trigger PMN-chemotaxis through activation of complement $\left(C^{\prime}\right)$ in uterine secretion, and the PMNs phagocytose non-viable spermatozoa in the presence of seminal plasma proteins. The inflammation results in the release of $\mathrm{PGF}_{2 \alpha^{\prime}}$ which induce myometrial contractions and facilitate clearance of the inflammation from the uterus. (Adapted from Troedsson and Madill, Pathophysiology of the Reproductive System. In: Veterinary Pathophysiology, Eds. Dunlop R. H. and Malbert C. H., Blackwell Publishing 2004).

Modellvorstellungen zur Entstehung einer Endometritis bei der Stute durch die Bedeckung/Besamung. Spermatozoen lösen die PMN-Chemotaxis über eine Aktivierung des Komplements ( $C^{\prime}$ ) im Uterussekret aus. Die PMNs phagozytieren nicht lebensfähige Spermatozoen in Anwesenheit der Proteine des Seminalplasmas. Die Entzündung führt zu einer Ausschüttung von PGF $2 \alpha^{\prime}$ welches die myometrialen Kontraktionen induziert und die Clearance der Entzündungsprodukte aus dem Uterus erleichtert. (Entnommen aus Troedsson and Madill, Pathophysiology of the Reproductive System. In: Veterinary Pathophysiology, Eds. Dunlop R. H. and Malbert C. H., Blackwell Publishing 2004).

ding to successful fertilization of an ovum in the oviduct, and for in utero survival and normal development of an embryo. New information in this area will likely aid the clinician in optimizing fertility when mares are bred by assisted reproductive techniques. 


\section{Literature}

Alghamdi A. S., Foster D. N. and Troedsson M. H. T. (2004): Equine seminal plasma reduces sperm binding to polymorphonuclear neutrophils and improves fertility of fresh semen inseminated into inflamed uteri. Reproduction 127, 593-600

Alghamdi A. S. and Foster D. N. (2005): Seminal DNAse frees spermatozoa entangeled in neutrophil extracellular traps (NETs). Biol. Repr. 73, 1174-1181

Asbury A. C., Schultz K. T., Klesius P H., Foster G. W. and Washburn S. M. (1982): Factors affecting phagocytosis of baceria by neutrophils in the mares uterus. J. Reprod. Fert. Suppl. 32, 151-159

Bader H. (1982): An investigation of sperm migration into the oviducts of the mare. J. Reprod. Fert. 32 (suppl), 59-64

Bader H. and Krause A. (1980): Investigations about the transport, distribution and the fate of spermatozoa in the genital tract of the mare. In: Proc. 9th Intl. Congr. Anim. Reprod. Al 5, 97-205

Blair W. D. and Beck L. R. (1977). In vivo effects of prostaglandin F2 and E2 on contractility and diameter of the rabbit oviduct using intraluminal transducers. Biol. Reprod. 16, 122-127

Brinkman V., Reichard U., Goosmann C., Fauler B., Uhlemann Y., Weiss D. S., Weinrauch Y. and Zychlinsky A. (2004): Neutrophil extracellular traps kill bacteria. Science, 203, 1532-1535

Brinsko S. P., Varner D. D., Blanchard T. L. and Meyers S. A. (1990): The effect of postbreeding uterine lavage on pregnancy rate in mares. Theriogenology 33, 465-475

Brinsko S. P. Varner D. D. and Blanchard T. L. (1991): The effect of uterine lavage performed four hours post-insemination on pregnancy rates in mares. Theriogenology 35, $1111-1191$

Claus R., Dimmick M. A., Gimenez T. and Hudson L. W. (1992): Estrogens and prostaglandin $F 2 \alpha$ in the semen and blood plasma of stallions. Theriogenology 38, 687-693

Dahms B. J. and Troedsson M. H. T. (2002): The effect of seminal plasma components on opsonisation and $\mathrm{PMN}$-phagocytosis of equine spermatozoa. Theriogenology 58, 457-460

Drobnis E. Z. and Overstreet J. W. (1992): Natural history of mammalian spermatozoa in the female reproductive tract. In: Oxford Rev. Reprod. Biol. 166-170

Fuchs A. R. (1972): Uterine activity during and after mating in the rabbit. Fert. Ster. 23, 915-923

Gustafsson B. K., Graham E. F., Crabo B. G., Pavelko M. K. and Wagner W. C. (1977): Pre-freeze supplementation of ram semen with PGE1 and PGF2 alpha: Effects on sperm vitality in vitro and on sperm transport in the ewe. In: Proc. Ann. Meeting Soc. Study Reprod., Austin TX. Abstract 10

Hunter A. G. and Nornes H. O. (1969): Characterization and isolation of sperm coating antigen from rabbit semen plasma with capacity to block fertilization. J. Reprod. Fert. 20, 419 (abstr)

Katila T. (1995): Onset and duration of uterine inflammatory response of mares after Insemination with fresh semen. Biol Reprod Mono 1: Equine ReproductionVI, 515-517

Katila T., Sankari S and Mäkelä O. (2000): Transport of spermatozoa in the reproductive tracts of mares. J. Reprod. Fert. 56 (suppl), $571-578$

Kotilainen T., Huhtinen M. and Katila T. (1994): Sperm induced leukocytosis in the equine uterus. Theriogenology 41, 629-636

Madill S., Troedsson M. H. T., Alexander S. L., Shand N. Santschi E. M. and Irvine C. H. G. (2000): Simultaneous recording of pituitary oxytocin secretion and myometrial activity in estrous mares exposed to various breeding stimuli. J. Reprod. Fert. Suppl. 56, 351-361

Metcalf E S. (2000): The effect of post-insemination endometritis on fertility of frozen stallion semen, in Proceedings. Am. Assoc. Equine Pract. 46, 330-331

Overstreet J. W. and Cooper G. W. (1978): Sperm transport in the reproductive tract of the rabbit. I. The rapid transit phase of transport. Biol. Reprod. 19, 101-114

Pavelko M. K. and Crabo B. G. (1976): Possible importance of some sperm coating proteins and their behaviour during preservation of boar semen. In: Proc. 8th Congr. Anim. Reprod. And Al. 3, 455-462

Phillips R. W. and Andrews F. N. (1937): The speed of travel of ram spermatozoa. Anat. Rec. 68, 127-132
Rodriguez-Martinez H. and Einarsson S. (1985): Influence of prostaglandins on the spontaneous motility of pig oviducts. Anim. Reprod. Sci. 8, 259-279

Rozeboom K. J., Troedsson M. H. T., Hodson H. H., Shurson G. C. and Crabo B. G. (2000): The importance of seminal plasma on spermatozoa viability of subsequent artificial inseminations in swine. J. An. Sci. 78, 443-448

Rozeboom K. J., Troedsson M. H. T., Rocha G. R. and Crabo B. G. (2001): The chemotactic properties of porcine seminal components towards neutrophils. J. Anim. Sci. 79, 996-102

Scott M. A. (2000): A glimpse at sperm function in vivo: sperm transport and epithelial interaction in the female reproductive tract. Anim. Reprod. Sci. 60, 337-348

Scott M. A., Liv I. K. M., Robertson K. R., Hanrath M., Overstreet J. W. and Drobnis E. Z. (1994): Acrosomal status and movement characteristics of sperm in the oviducts of normal mares. In: Proc. Int. Symp. Eq. Reprod. VI 173-174

Scott M. A. Liu I. K. M. and Overstreet J. W. (1995): Sperm transport to the oviducts: Abnormalities and their clinical implications. In: Proc. Am. Assoc. Equine. Pract. 41, 1-2

Taylor N. J. (1982): Investigation of sperm-induced cervical leukocytosis by a double mating study in rabbits. J. Reprod. Fert. 66, 157160

Troedsson M. H. T., Liu I. K. M. and Thurmond M. (1993): Immunoglobulin ( $\lg G \& \lg A)$ and complement (C3) concentrations in uterine secretion following an intrauterine challenge of Streptococcus zooepidemicus in mares susceptible and resistant to chronic uterine infection. Biol. Reprod. 49, 502-506

Troedsson M. H. T., Steiger B. N., Ibrahim N. M., Foster D. N. and Crabo B. G. (1995a): Mechanisms of sperm induced endometritis in the mare. Biol. Reprod. Suppl. 52, 307 (abstr)

Troedsson M. H. T., Liu I. K. M., Ing M. and Pascoe J. (1995b): Smooth muscle electrical activity in the oviduct and the effect of oxytocin $\mathrm{PGF}_{2 \alpha^{\prime}}$ and $\mathrm{PGE}_{2}$ on the myometrium and the oviduct of the cycling mare. Biol. Reprod. Mono. 1: Equine Reproduction VI, 439-452

Troedsson M. H. T, Liu I. K. M. and Crabo B. G. (1998): Sperm transport and survival in the mare: A review. Theriogenology 50, 807 818

Troedsson M. H. T. (1999): Uterine clearance and resistance to persistent endometritis in the mare. Theriogenology 52, 461-471

Troedsson M. H. T., Lee C.-S., Franklin R. and Crabo B. G. (2000): The role of seminal plasma in post-breeding uterine inflammation. J. Reprod. Fert. Suppl. 56, 341-349

Troedsson M. H. T., Loseth K., Alghamdi A. M., Dahms B. and Crabo B. G. (2002): Interaction between equine semen and the endometrium: The inflammatory response to semen. An. Reprod. Sci. 68, 273-278

Troedsson M. H. T., Alghamdi A. S., Desvousges A., Dahms B., Dow C. A., Hayna J., Valesco R., Collahan P. T., Macpherson M. L., Pozor M. and Buhi W. C. (2005): Components in seminal plasma regulating sperm transport and elimination. Anim. Reprod. Sci, $89,171-186$

VanDemark N. L. and Moeller A. N. (1951): Speed of spermatozoan transport in the reproductive tract of estrus cows. Am. J. Physiol. $165,674-679$

Watson E. D., Stokes C. R. and Bourne F. J. (1987): Cellular and humoral mechanisms in mares susceptible and resistant to persistent endometritis. Vet. Immun. Immunopath. 16, 107-121

Prof. Mats H. T. Troedsson

Department of Large Animal Clinical Sciences

College of Veterinary Medicine

University of Florida

Gainesville, FL 32610

TroedssonM@mail.vetmed.ufl.edu 